\title{
The park $t$
}

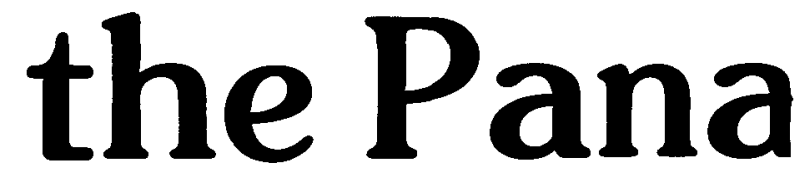

Nicholas Smythe

The forests flanking the Panama Canal were protected in its early days for military reasons. Today the forest is seen to be essential to protect water supplies both for people and for the operation of the canal, and Panama has wisely created a national park. The Parque Nacional Soberania preserves 22,000 hectares of Neotropical forest and its wildlife. The author, who has been working in the area for the past 15 years, points out some of the park's advantages and difficulties.

On 28 August 1981, the Parque Nacional Soberania was inaugurated by the Panamanian Institute of Renewable Natural Resources. The creation of any national park is noteworthy but these 22,000 hectares are important both in the struggle to preserve part of the remaining Neotropical forests and in having several unusual, if not unique, features. In the first place, there are excellent economic reasons for preserving the forest in the area. In the continuing battle against exploitation, the conservationist is often frustrated in trying to find a persuasive rationale for protecting a stretch of wilderness, especially in developing countries, where popular emphasis is generally on the quickest possible exploitation of any resource. But the Parque Nacional Soberania is a critical part of the watershed basin of the Panama Canal, and the soil erosion that would result from destroying the forest here would not only jeopardise the water supply for half Panama's population but also, since the operation of the canal is totally dependent on the 42 freshwater reservoir, would seriously endanger this, the country's major economic resource. It would be difficult to find more persuasive arguments against exploitation than these.

A second unusual feature of this park is that it has some financial support. Even in those countries where the population is environmentally sophisticated, national parks tend to become Cinderellas at budget time. But Soberania has a fairy godmother in the United States Agency for International Development (USAID). In 1979, when the new Panama Canal Treaty between the US and Panama was implemented, it was realised that the essential watershed basin was coming under increasing pressure from various forms of exploitation, and that without protection the remaining forest would surely be destroyed. To help ensure rational use of the watershed USAID therefore made a load to the Panama Government which included some funds for the development of a national park. Thus, while the park is not affluent, there is sufficient money for the initial development stages.

A new national park with what appears to be a cast-iron rationale for its existence and with sufficient funds to make it an operating reality is indeed an unusual phenomenon. However, the third characteristic, which makes it a rarity, is both its greatest advantage and its most menacing threat: easy accessibility. In other national parks created in the Neotropics within the last few years the forests have been too far from population centres to have tempted the exploiters, or are undesirable for other reasons. Thus new national parks have been in remote and inaccessible places. But Parque Nacional Soberania has a Oryx Vol 18 No 1 


\section{hat protects ma Canal}

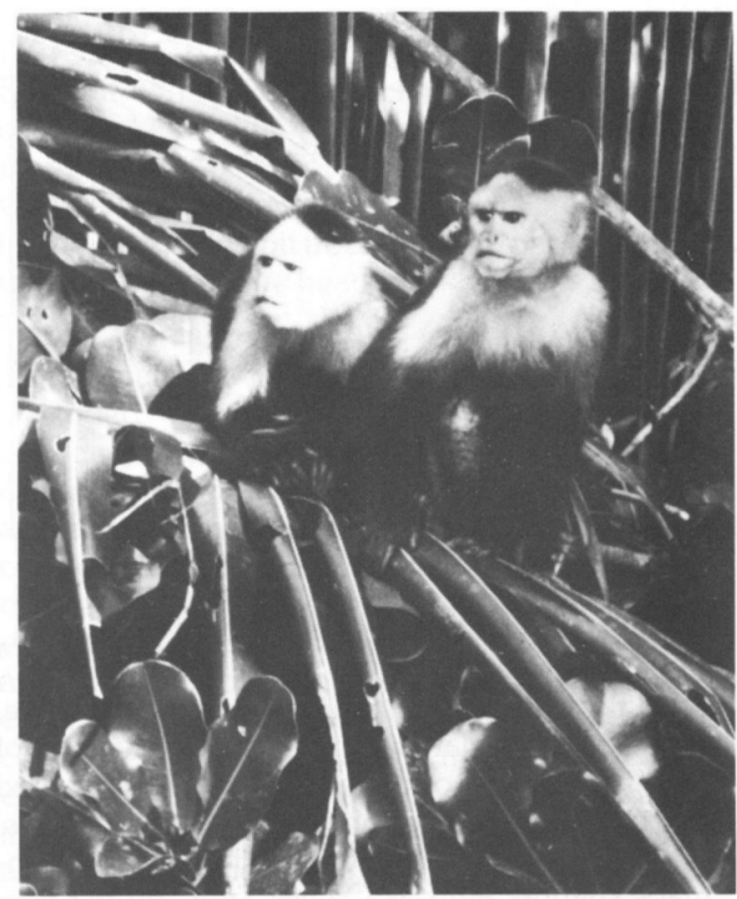

Above: White-throated capuchins Cebus capucinus can be found in the areas of older forest (N. Smythe).

Right: Geoffroy's tamarins Sanguinus geoffroyi are common in the Park although their numbers are dwindling in many places because of pressure from the pet trade ( $N$. Smythe).

sizeable area of magnificently forested wilderness within an hour or less, by road or rail, of Panama's two major population centres, and is on the very edge of a canal that is one of the world's major tourist routes.

The potential advantages of easy access are many, notably for environmental education. School children can be brought in easily and introduced to conservation concepts at the most Park that protects the Panama Canal

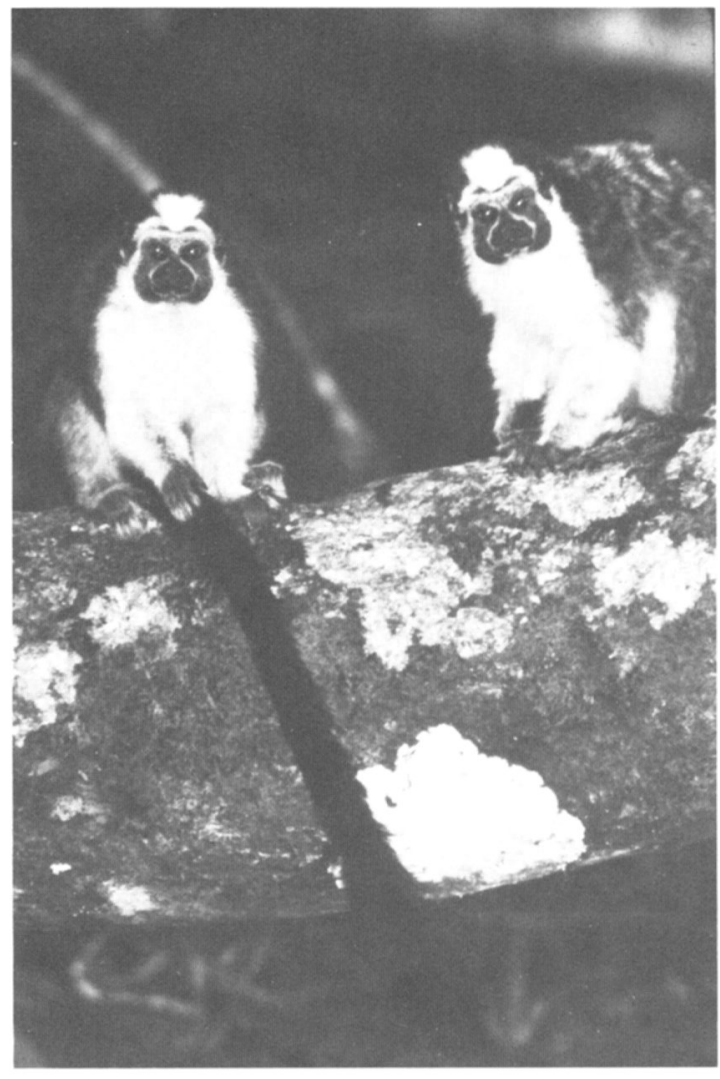

important age. Also, with appropriate planning, the park can be managed for conservation and simultaneously attract tourists who bring revenue for its upkeep. Provision for staff can be of a better standard than in remote areas, and higher quality facilities will give visitors a positive first wilderness experience', and a wish to see more parks elsewhere. But unexploited areas near large population centres also immediately attract 


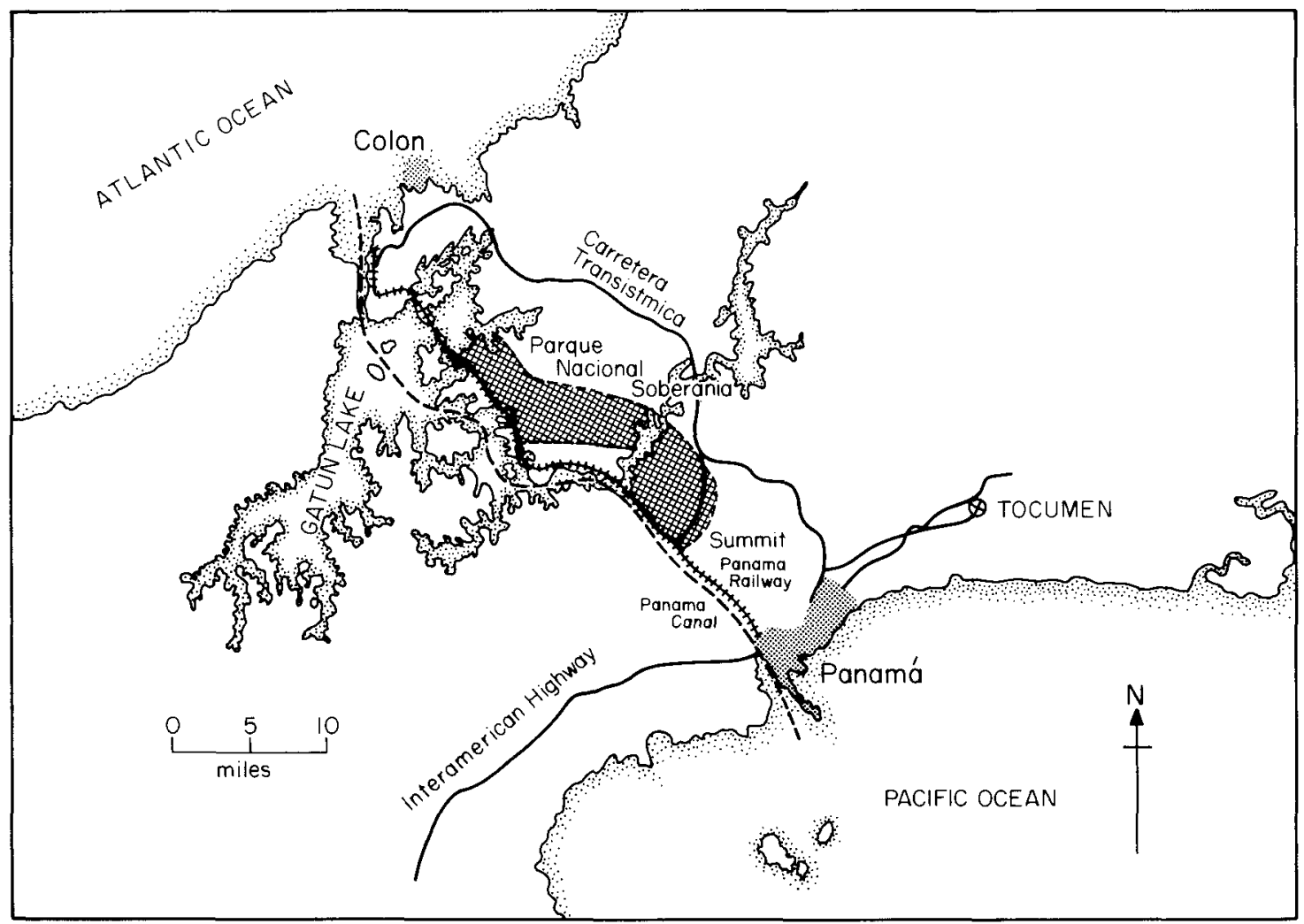

Map showing location of Parque Nacional Soberania.

would-be farmers, poachers and land developers, especially in the tropics where forest is regarded as the traditional enemy and replacing it with plantations or pasture the only logical form of progress. The task of protecting such areas becomes enormous. How, then, did the area of Parque Nacional Soberania remain unexploited for so long?

During the Spanish conquest the city of Panama became the temporary depository of the gold that was looted from the New World civilisations. From there it was carried to Las Cruces on the Chagres river or Portobelo on the Altantic coast by overland trails. The most famous of these trails, the Las Cruces trail, goes through the park, and parts are still in remarkably good condition. This was the route followed by Henry Morgan to reach, and sack, the old city of Panama, and by many who followed the gold rush to California in 1849.

44
Until the late 1800s Panama remained a remote, sparsely populated, northern province of Colombia. Most of the active land use occurred then, as now, along the major transport routes, and probably much of the forest beside the highways such as the Las Cruces Trail and the river Chagres, was felled and the land used for agriculture. But the western part of the park is hilly and difficult to cultivate, so some forest there may never have been cleared, although there may have been selective logging to build and maintain the original Panama railway (1850-1906) or the many miles of railway used in building the canal (1881-1914).

Panama became independent in 1904 and simultaneously ratified a treaty allowing the United States to control the Canal Zone, an 800 square-mile ( $2070 \mathrm{sq} \mathrm{km}$ ) strip of land 5 miles ( 8 $\mathrm{km}$ ) wide on either side of the proposed canal route. The first governor, Colonel George Oryx Vol 18 No 1 
Goethals, saw the 'jungle' as effective protection against military attack, and the policy was to preserve the remaining forest and encourage the restoration of what had already been destroyed. No land in the Zone could be privately owned and, except for a few non-transferrable land licences granted to construction workers (the last in 1924), no settlement outside the planned communities was permitted.

So the park area, particularly the part which lies west of the Chagres, was practically unvisited, except by occasional hunters, between the building of the canal and the Second World War. In 1923 a botanic garden was established at Summit - the point at which the canal crosses the continental divide-and over 10,000 tropical plant species planted, many of which have survived to form an extraordinary collection, including many exotic fruit trees that may have potential use in Panama. The headquarters of the new park are here.

The Japanese capture of Singapore in 1942 exploded the myth that tropical vegetation affords protection against military attack. The canal no longer appeared invulnerable, so the US army built a road and the navy an oil pipeline to connect Colon and Panama city. The road opened the way for exploitation and the land on either side was quickly deforested. But public access to the road along the pipeline was not so easy, and at times, until the middle 1960s, was completely prohibited as the military carried out exercises there. So the forest remained largely intact. Gradually it became known to naturalists and hunters, and a hunting club was established on the road for the use of Canal Company employees. Market hunters from Panama city were a more serious problem however, and hundreds, if not thousands, of white-tailed deer Odocoileus virginianus, peccaries Tayassu tajacu, and pacas Cuniculus paca (a large rodent and favourite game animal) as well as iguanas Iguana iguana and crocodiles Crocodylus acutus, were taken for sale in the city markets. Commercial hunting was prohibited by law in 1967, but, until 1978 , with no closed season and using dogs against which local animals have never evolved any defences, 'sport' and 'pot' hunting increased to an extent that affected the game animal populations.

Park that protects the Panama Canal
As pressures from hunting increased, so too did the interest of naturalists, professional and amateur. The 'Pipeline Road' became well known both locally and internationally as the place to see the flora and fauna; many biologists came to Panama especially to research and collect in the area. Then, in 1978, Governor Parfitt banned hunting in the pipeline area. Little was done to enforce this edict, but hunting certainly decreased.

On 1 October 1979 the new Panama Canal treaty was ratified and the park area was among the lands returned to Panamanian control. President Royo foresaw the dangers of exploiting the watershed forest, and on 27 May 1980 issued a decree setting up the new national park, to be called La Libertad, later changed to Soberania.

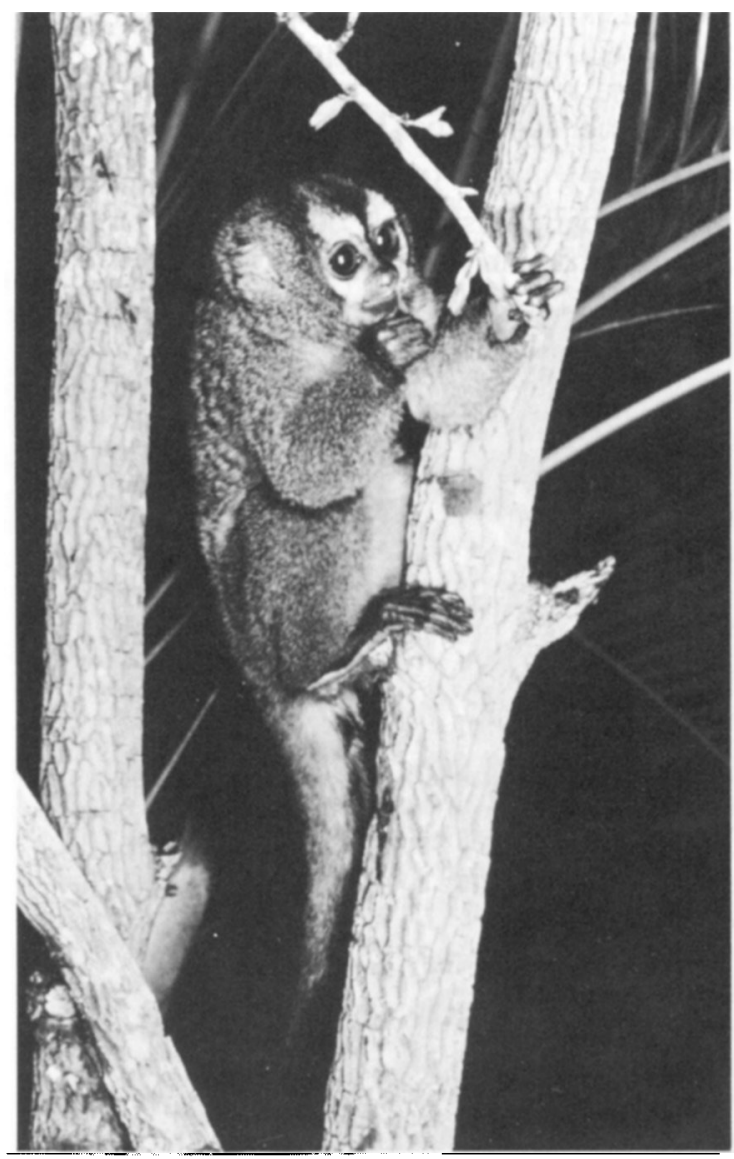

Night monkeys Aotus trivirgatus can be readily seen and heard where the road runs through the forest (N. Smythe). 
The new national park has enormous potential. Probably no other Latin American capital can claim to have wild jaguars so close. Among more than 100 mammal species are eight which are on the international endangered species list: American manatee Trichechus manatus, Central American river otter Lutra annectens, tapir Tapirus bairdii, ocelot Felis pardalis, margay F. weidi, jaguarundi $F$. yagouarundi, mantled howler monkey Alouatta palliata and Geoffroy's marmoset Saguinus geoffroyi.

The 365 birds include the harpy eagle Harpia harpyia, the most powerful eagle in the world and Panama's national bird. Seventy-nine species of reptiles, 55 amphibians and 36 freshwater fishes round out the impressive inventory of vertebrates. Insects occur in incredible variety; the real number will probably never be known but they include more than 300 butterflies, for which a field guide is being prepared. Flowering plants total nearly 2000 , and a guide to 300 of the commoner species has been written.

What of the future? With so much in its favour this national park must surely be a success. But Latin America has no tradition of biological conser-

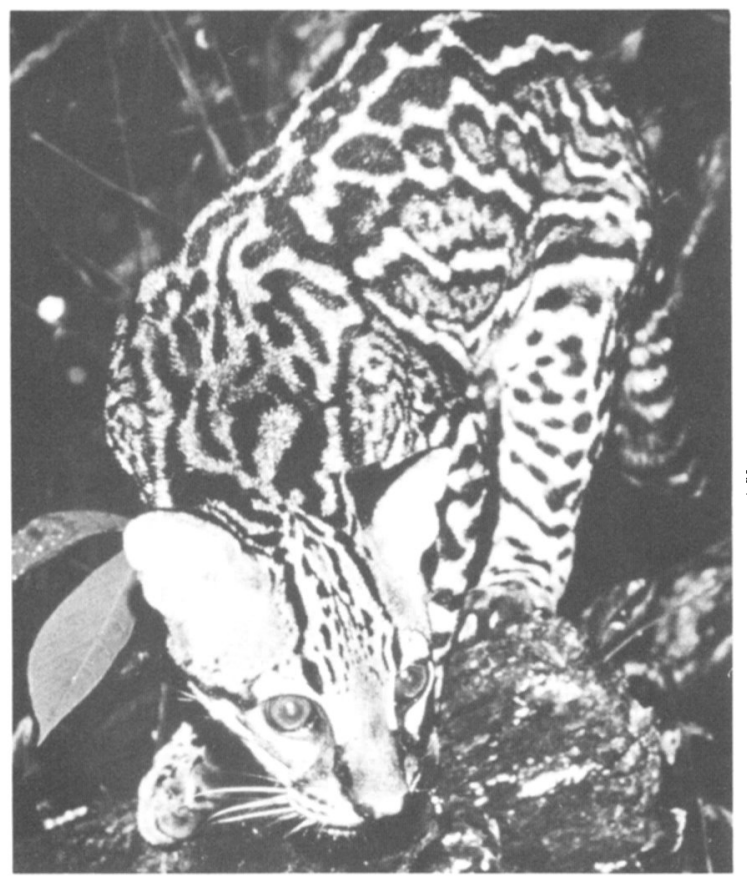

Ocelots are fairly common in the Park (N. Smythe)

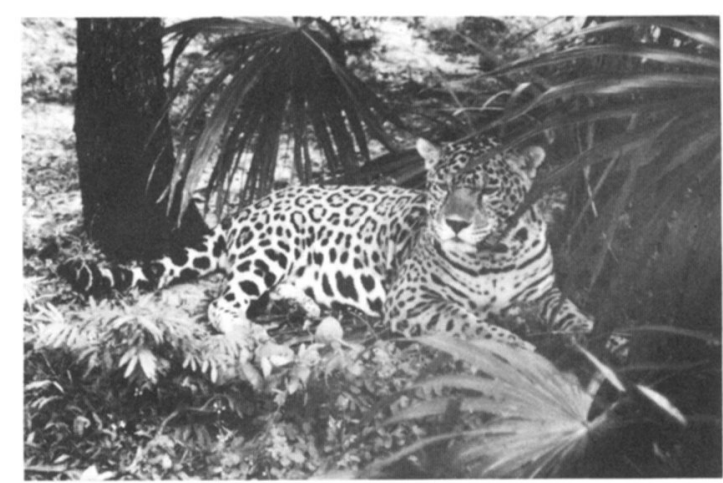

Jaguar - a pair is occasionally seen in the Park (N. Smythe).

vation and success may be difficult to achieve. Because of the nature of the climate and of the biota, new forms of protection, management and environmental interpretation will have to be developed. The birds and mammals are seldom as spectacularly viewable as they are in many other habitats, and the pleasure of a long hike to an overnight camping spot distinctly pales in the enervating heat and saturating humidity. It will not be possible simply to transfer techniques from other parts of the world and assume that they will work as well here. In a very real sense Parque Nacional Soberania is a bell-wether for other parks and for conservation in the Neotropical forest. Eventually even the remotest of parks will be subjected to pressures similar to those felt here. If this park succeeds, the lessons learned will be valuable.

Nicholas Smythe, Smithsonian Tropical Research Institute, Box 2072, Balboa, Panama.

\section{Binders for Oryx}

Binders to hold eight issues (two years' supply) of Oryx are available from the ffPS office. The binders are black, stamped with Oryx and the oryx head logo in silver on the spine, and cost $£ 4.00$ each including posting and packing. They will be sent second class for UK orders and printed matter/reduced rate for overseas orders. 